\title{
NOTES
}

\section{“ASHES OF SOLDIERS": WALT WHITMAN AND C. H. SHOLES, A NEW LETTER AND A NEWSPAPER ARTICLE}

On February 20, 1880, Walt Whitman sent the circular for the 1876 editions of Leaves of Grass and Two Rivulets to a short-hand reporter in Iowa named C. $\mathrm{H}$. Sholes - presumably at his request (DBN 173). He received in return an admiring letter from Sholes on March 12, along with an order for both volumes. On a slip of paper later pasted into his daybooks, Whitman noted that Sholes was an "admirer of L of G-bo't the book (ardent letter from him March '80)" (DBN, 131). The following is Whitman's previously unpublished response to Sholes, now in the Kendall Reed Collection:

TO C. H. SHOLES

ADDRESS: C H Sholes / Glenwood

/ Mills Co: Iowa / POSTMARK:

Philadelphia PA / Mar / 12 / 5 PM

Camden New Jersey

March 12 pm-Yours duly rec'd-I send you by mail to-day, to same address as this card, my Two Vols, Leaves of Grass and Two Rivulets-Please send me a card informing me if they reach you safely-

\section{Walt Whitman}

Sholes received the package (an 1876 edition of Two Rivulets was recently offered for sale by D \& D Galleries of Somerville, New Jersey, with the inscription: "C. H. Sholes / from the author"), but, if he sent a postcard confirming the shipment, Whitman did not note it in the daybooks. However, Sholes soon wrote an article revealing the extent of his admiration for Whitman. On Decoration Day, May 30, 1880, he published in the Iowa State Register the following article, reprinted here for the first time:

\section{ASHES OF SOLDIERS.}

On this occasion of decorating the graves of the brave men who valued their country more than their own lives, when little children shall strew them with the flowers of May, and strong men shall speak eloquent words and shed the more eloquent tear, nothing could be more appropriate than the following beautiful poem, written by one who well knew the hardships of the soldier's life. The author, Walt Whitman, who attains his sixty-first birthday to-morrow, the 31st of May, gave three years of arduous labor to nursing the sick and wounded on the field and in the hospitals. There are many 
soldiers in the North who remember his kind face and sympathizing words as he walked through the wards carrying baskets of food and fruit to some, giving papers, books and money to others, writing letters home to parents, wives and lovers, washing and dressing wounds, reading to dying men from worn and blood-stained bibles, and bending to kiss some pale, pain-distorted face. Many a mother cherishes a tenderly-written letter signed "W. W." as the last precious relic of her soldier-boy who sleeps upon a southern battle-field.

Walt Whitman's memoranda during the war, Drum-Taps, and Lincoln's Burial Hymn, constitute the most touching and thrilling memorials of the rebellion that we possess; indeed they are the only adequate embodiment of the heroic spirit of the time. His intense devotion to the cause and the exposure resulting therefrom, induced an attack of paralysis from which the author has not fully recovered. While the nation mourns for its illustrious heroes, and joins to-day in rendering unto them the honor which is their due, let one garland be woven in memory of the soldiers' noblest friend and poet-Walt Whitman.

Following is the poem, and although not written with special reference to this occasion, is most appropriately called "Ashes of Soldiers": [the text of the 1876 version of "Ashes of Soldiers" follows].

Sholes sent Whitman copies of the article, which Whitman acknowledged on June 9 from Maurice Bucke's home in London, Ontario: "I have rec'd the two Iowa papers, with my soldiers' poem commemorative of Decoration daybelieve me I appreciate your kind mention-" (Corr 3: 181). Whitman's letter would seem to indicate that another newspaper reprinted Sholes' article, but it has not been located to date. Upon learning that Whitman was in London, a good deal closer than Camden to Des Moines, Sholes traveled to Bucke's home to meet his revered poet. Whitman had little to say of the meeting, recording in the daybooks only that "C $\mathrm{H}$ Sholes called" and that they met in "Dr B's library-London" ( $D B N$ 193). There appears to have been no further communication between the two men. 